\title{
Antioxidant Activity and Lipoxygenase Enzyme Inhibition Assay with Total Flavonoid Content from Garcinia hombroniana Pierre Leaves
}

Shinta Marlin, Berna Elya*, Katrin

Shinta Marlin, Berna Elya, Katrin Faculty of Pharmacy, Universitas

Indonesia, Depok, Jawa Barat, 16424, INDONESIA.

\section{Correspondence}

\section{Berna Elya}

Gedung A Rumpun Ilmu Kesehatan Lantai 1, Kampus UI, Depok, Jawa Barat 16424, INDONESIA.

Phone: 021-7270031/02178849001-3

E-mail: berna.elya@gmail.com

\section{History}

- Submission Date: 21-12-2016;

- Review completed: 05-01-2017;

- Accepted Date: 16-01-2017.

DOI : 10.5530/pj.2017.2.45

Article Available online http://www.phcogj.com/v9/i2s

\section{Copyright}

(C) 2017 Phcog.Net. This is an openaccess article distributed under the terms of the Creative Commons Attribution 4.0 International license.

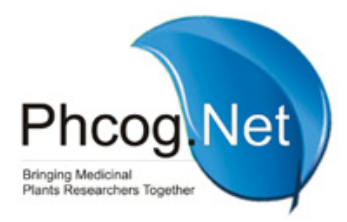

\begin{abstract}
Objective: Garcinia hombroniana Pierre leaves extract have been known to contain flavonoid, but it has not been known yet for its antioxidant activity and inhibition of lipoxygenase activity. This study aims to determine antioxidant activity and inhibition of lipoxygenase activity of $G$. hombroniana leaves extract. Method: Antioxidant activity tested by using FRAP (Ferric Reducing Antioxidant Power) method and inhibition of lipoxygenase activity using baicalein as the positive control. Total flavonoid assay is also quantitatively done by $\mathrm{AlCl}_{3}$ colorimetric method on the most active extract using quercetin as the positive control. Results: The test result showed that the $n$-hexane, ethyl acetate and methanol extract of $G$. hombroniana Pierre leaves have antioxidant activity which showed by $\mathrm{EC}_{50}$ value consecutively are $36.260 ; 2.969$; and $7.416 \mu \mathrm{g} / \mathrm{mL}$, and also can inhibit lipoxygenase activity which showed by $I C_{50}$ value consecutively are $2.052 ; 0.134$; and $1.314 \mu \mathrm{g} / \mathrm{mL}$. Ethyl acetate extract of $G$. hombroniana Pierre leaves has the most active antioxidant activity and inhibition of lipoxygenase activity. Total flavonoid content of ethyl acetate extract of $\mathrm{G}$. hombroniana Pierre leaves is $42.004 \mathrm{mg} \mathrm{QE} / \mathrm{g}$ sample. Conclusion: Garcinia hombroniana Pierre leaves extract has antioxidant activity and can inhibit lipoxygenase activity.
\end{abstract}

Key words: Antioxidant, Antiinflammation, Flavonoid, Garcinia hombroniana Pierre, FRAP, lipoxygenase.

\section{INTRODUCTION}

Plants contain various chemical compounds such as phenolic, flavonoid, carotenoid, steroid, and thiol compound that may help protect cells from oxidative stress damage and reduce the risk of chronic disease. Flavonoid such as catechin and epicatechin can be used for the activity of antioxidant and anti-inflammatory. ${ }^{1}$

Garcinia hombroniana Pierre are in Indonesia, one of them in the Bogor Botanical Garden, but has not been much research on this plant. People familiar with $G$. hombroniana Pierre as mangosteen family of plants that are ornamental plants, food crops, and as a traditional medicine for itchy. ${ }^{2}$ Previous research has been conducted on the bark of $G$. hombroniana Pierre which showed that the ethyl acetate extract had the highest content of flavonoid and antioxidant activity $\mathrm{EC}_{50}$ values obtained by FRAP method is $5579.8 \pm 117.7 \mathrm{~mol} \mathrm{TE}$ (Trolox Equivalent)/g. ${ }^{2}$

Garcinia hombroniana Pierre leaves extract have been known to contain flavonoid, ${ }^{3}$ but it has not been known yet for its antioxidant activity and inhibition of lipoxygenase activity. This study aims to determine antioxidant activity tested by using FRAP (Ferric Reducing Antioxidant Power) method and inhibition of lipoxygenase activity of $G$. hombroniana leaves extract. This research is expected to provide information on the strength of antioxidant activity and inhibition of lipoxygenase activity in the most active extract of $n$-hexane, ethyl acetate, and methanol leaves of G. hombroniana Pierre as a source of antioxidant and anti-inflammatory.

\section{MATERIALS AND METHODS}

\section{Antioxidant Activity Assay}

For the antioxidant activity assay, $3.8 \mathrm{~mL}$ FRAP reagent solution reacted with $0.2 \mathrm{ml}$ baicalein solution or sample, then incubated for 30 minutes at $37^{\circ} \mathrm{C}$. The solution absorbance was measured at $595 \mathrm{~nm}$. For sample or standard control, $3.8 \mathrm{~mL}$ FRAP reagent solution reacted with $0.2 \mathrm{ml}$ ethanol pro analysis, then treated the same as well as the sample or standard.

The percentage of capacity can be calculated using this equation:

$\%$ Capacity $=(1-\mathrm{Ts}) \times 100 \%$

Ts $=$ Transmittan

As $=-\log \mathrm{Ts}$

As = Absorbance of standard or sample solution Absorbance of reference solution

$\mathrm{EC}_{50}$ value gained by using Microsoft Office Excel and GraphPad Prism 7.

\section{Lipoxygenase Enzyme Inhibition Assay}

For the lipoxygenase enzyme inhibition assay, first to be optimized $\mathrm{pH}$ borate buffer solution, stop solution, enzyme concentration, and substrate concentration. Test of inhibition of lipoxygenase activity carried out by reacting $10 \mathrm{~mL}$ of baicalein or sample solution (various concentration) with $1690 \mathrm{~mL}$ of 0.2 
M borate buffer $\mathrm{pH} 8.5$ and $1000 \mathrm{~mL}$ of linoleic acid solution $(900 \mu \mathrm{M})$. The mixture solution was then incubated for 10 minutes at $25^{\circ} \mathrm{C} .300$ $\mathrm{mL}$ of lipoxygenase solution (5000 units/mL) was added and incubated another 15 minutes at $25^{\circ} \mathrm{C}$. $1000 \mathrm{~mL}$ of stop solution is added and measured its absorbance using UV-Vis spectrophotometer at $235 \mathrm{~nm}$.

Inhibition of the activity of lipoxygenase can be known from the value of the inhibition percentage that was calculated using the following equation:

$\%$ lipoxygenase inhibition $=\frac{(\mathrm{A}-\mathrm{B})-(\mathrm{C}-\mathrm{D})}{(\mathrm{A}-\mathrm{B})} \times 100 \%$

$\mathrm{A}=$ Absorbance of reference solution with enzyme

$\mathrm{B}=$ Absorbance of reference solution without enzyme

$\mathrm{C}=$ Absorbance of standard or sample solution with enzyme

$\mathrm{D}=$ Absorbance of standard or sample solution without enzyme

$\mathrm{IC}_{50}$ value gained by using Microsoft Office Excel and GraphPad Prism 7.

\section{Thin Layer Chromatography (TLC) Analysis}

Analysis by thin layer chromatography (TLC) was conducted to determine the leaves extract of Garcinia hombroniana that have the highest content of flavonoid qualitatively. Eluent used after optimization of the mobile phase is ethyl acetate-formic acid (40:1) for methanol extract, toluene-ethyl acetate-formic acid (61:30:9) for ethyl acetate extract and n-hexane-ethyl acetate (6:4) for n-hexane extract. The plate of silica gel $60 \mathrm{~F}_{245}$ is used as the stationary phase.

In this TLC analysis, quercetin is used as a standard solution that is treated similarly to the extract. The distance covered by the standard solution ( $\mathrm{Rf}$ standard) is then compared to the distance traveled by each extract (Rf sample).

\section{Determination of the total flavonoid content (TFC)}

For total flavonoid content, $0.5 \mathrm{~mL}$ standard or sample solution was reacted with $1.5 \mathrm{~mL}$ methanol pro analysis; $0.1 \mathrm{~mL} \mathrm{AlCl}_{3} 10 \% ; 0.1 \mathrm{~mL} 1 \mathrm{M}$ sodium acetate solution; and $2.8 \mathrm{~mL}$ distilled water. The mixture solution was incubated for $30 \mathrm{~min}$ at room temperature. Absorption was measured by using UV-VIS spectrophotometer at $435 \mathrm{~nm}$. The calibration curve of quercetin was required to obtain the linear regression equation so that the level of flavonoid in the sample can be calculated.

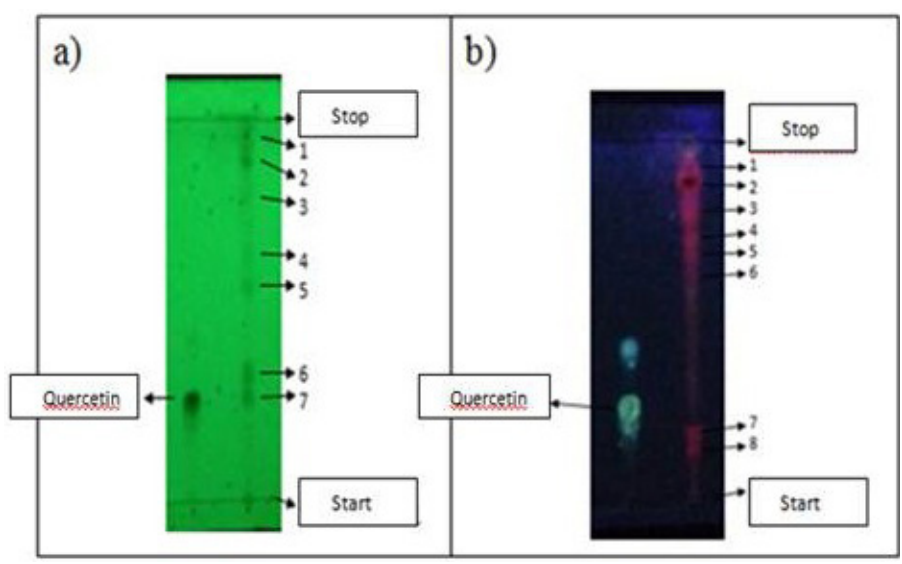

Figure 1: TLC result of $\mathrm{n}$-hexane extract of the leaves of $\mathrm{G}$. hombroniana at $254 \mathrm{~nm}(\mathrm{a})$ and $366 \mathrm{~nm}(\mathrm{~b})$.

\section{RESULTS}

\section{Antioxidant Activity Assay}

Test of antioxidant activity using baicalein as the positive control. The test result obtained $\mathrm{EC}_{50}$ value of baicalein is $1.165 \mu \mathrm{g} / \mathrm{mL}$ (Table 1). The test result of extract n-hexane, ethyl acetate and methanol leaves of $G$. hombroniana obtained EC50 values consecutively are 36.260; 2.969; and $7.416 \mu \mathrm{g} / \mathrm{mL}$ (Table 2).

\section{Lipoxygenase Enzyme Inhibition Assay}

Lipoxygenase inhibition test is done by using baicalein as a positive control. The test result obtained $\mathrm{IC}_{50}$ value of baicalein is $0.250 \mu \mathrm{g} / \mathrm{mL}$ (Table 3 ). The test result of extract n-hexane, ethyl acetate and methanol leaves of $G$. hombroniana obtained IC50 values consecutively are 2.052; 0.134; and $1.314 \mu \mathrm{g} / \mathrm{mL}$ (Table 4).

\section{Thin Layer Chromatography (TLC) Analysis}

Analysis with TLC (Thin Layer Chromatography) was conducted to determine the presence of flavonoid in the extract n-hexane, ethyl acetate and methanol leaves of G. hombroniana qualitatively. The TLC result showed that there aren't any flavonoid in the n-hexane and methanol extract, (Figure 1 and 3) but there is flavonoid in the ethyl acetate extract of the leaves of G. hombroniana (Figure 2).

Analysis by TLC (Thin Layer Chromatography) gave the result that ethyl acetate extract of the leaves of G. hombroniana has the highest content of flavonoid. Then the ethyl acetate extract of the leaves of G. hombroniana undergoes the determination of total flavonoid content by $\mathrm{AlCl}_{3}$ colorimetric method.

\section{Determination of the total flavonoid content (TFC)}

The standard solution with the various concentration of quercetin used to create a calibration curve ${ }^{6}$ (Table 5 ). The absorbance of ethyl acetate extract of leaves of $G$. hombroniana plotted against the quercetin calibration curve and then calculated its total flavonoid content. The content of flavonoid in the sample expressed in $\mathrm{QE}$ (quercetin Equivalent). QE is the equality number of milligram quercetin in 1 gram sample. The result obtained total flavonoid content of ethyl acetate extract of the leaves of G. hombroniana is $42.004 \mathrm{mg} \mathrm{QE} / \mathrm{g}$ sample.

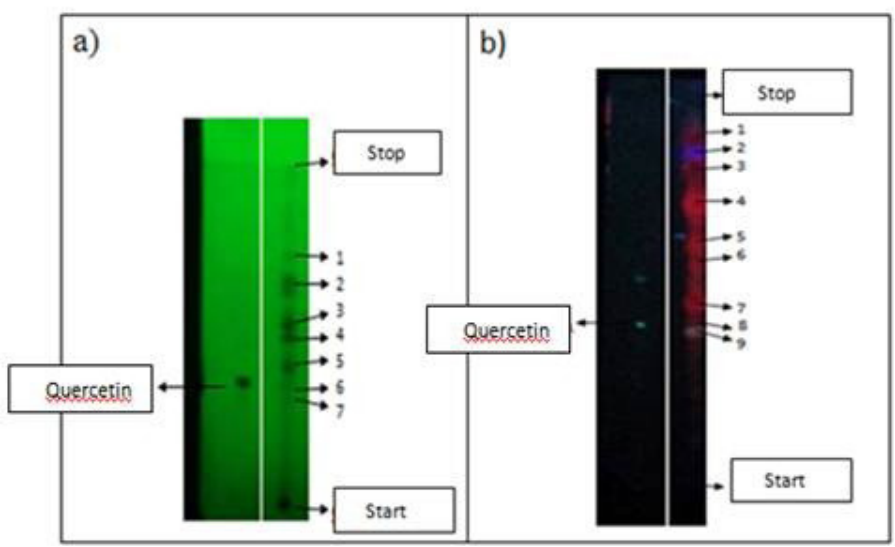

Figure 2: TLC result of ethyl acetate extract of the leaves of G. hombroniana at $254 \mathrm{~nm}$ (a) and $366 \mathrm{~nm}$ (b). 


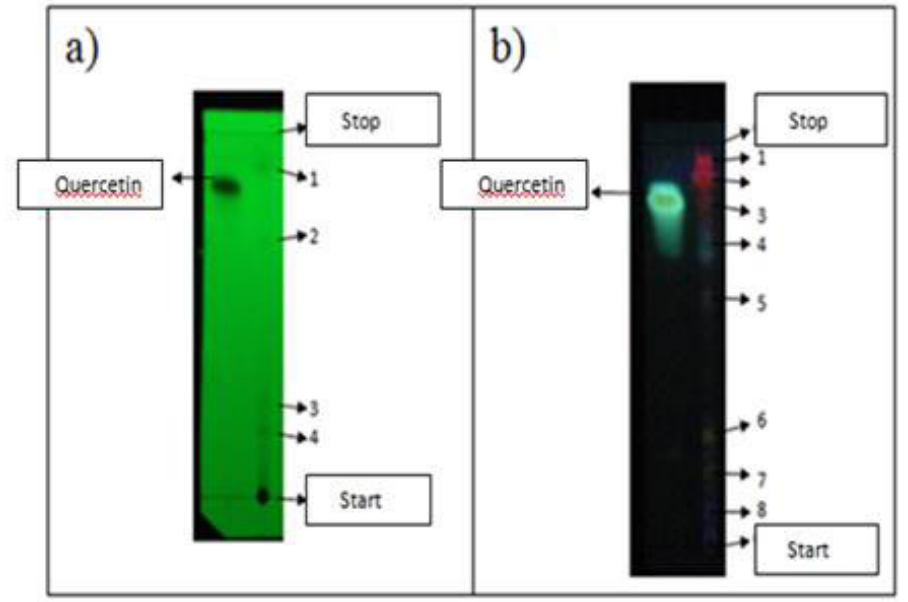

Figure 3: TLC result of methanol extract of the leaves of $\mathrm{G}$. hombroniana at $254 \mathrm{~nm}$ (a) and $366 \mathrm{~nm}$ (b).

Table 1: Capacity percentage of baicalein against FRAP and $\mathrm{EC}_{50}$ value of baicalein

\begin{tabular}{ccccccc}
\hline Sample & $\begin{array}{c}\text { Sample } \\
\text { Concentration } \\
(\mu \mathrm{g} / \mathrm{mL})\end{array}$ & $\begin{array}{c}\text { Capacity } \\
\text { percentage (\%) }\end{array}$ & $\begin{array}{c}\text { Standard } \\
\text { Deviation } \\
(\mathrm{SD})\end{array}$ & $\begin{array}{c}\text { Coefficient of } \\
\text { Variation }(\%)\end{array}$ & $\begin{array}{c}\text { Regression } \\
\text { Equation }\end{array}$ & $\begin{array}{c}\mathrm{EC}_{50} \\
(\mu \mathrm{g} / \mathrm{mL})\end{array}$ \\
\hline \multirow{6}{*}{ Baicalein } & 0.508 & 31.188 & 0.003 & 1.423 & & \\
& 0.762 & 40.297 & 0.001 & 0.418 & $\mathrm{y}=17.6646+$ & 1.165 \\
& 1.016 & 45.592 & 0.005 & 1.424 & $27.7559 \mathrm{x}$ & \\
& 1.270 & 52.612 & 0.001 & 0.307 & & \\
\hline
\end{tabular}

Table 2: Capacity percentage and $\mathrm{EC}_{50}$ value of the leaves extract of $\mathrm{G}$. hombroniana

\begin{tabular}{|c|c|c|c|c|c|c|}
\hline Sample & $\begin{array}{c}\text { Sample } \\
\text { Concentration } \\
(\mu \mathrm{g} / \mathrm{mL})\end{array}$ & $\begin{array}{c}\text { Capacity } \\
\text { percentage } \\
(\%)\end{array}$ & $\begin{array}{l}\text { Standard } \\
\text { Deviation } \\
\text { (SD) }\end{array}$ & $\begin{array}{l}\text { Coefficient of } \\
\text { Variation (\%) }\end{array}$ & $\begin{array}{l}\text { Regression } \\
\text { Equation }\end{array}$ & $\begin{array}{c}\mathrm{EC}_{50} \\
(\mu \mathrm{g} / \mathrm{mL})\end{array}$ \\
\hline \multirow{6}{*}{ n-hexane extract } & 19.984 & 27.334 & 0.011 & 5.371 & & \multirow{6}{*}{36.260} \\
\hline & 24.980 & 37.483 & 0.005 & 1.916 & & \\
\hline & 29.976 & 40.434 & 0.007 & 2.347 & $y=\frac{100}{1+10^{\wedge}[(1,559-x) * 1,611]}$ & \\
\hline & 39.968 & 52.902 & 0.008 & 1.963 & $R^{2}=0.9875$ & \\
\hline & 44.964 & 60.250 & 0.010 & 2.115 & & \\
\hline & 49.960 & 62.330 & 0.004 & 0.837 & & \\
\hline \multirow{6}{*}{$\begin{array}{l}\text { ethyl acetate } \\
\text { extract }\end{array}$} & 2.007 & 29.801 & 0.006 & 2.826 & & \multirow{6}{*}{2.969} \\
\hline & 2.509 & 41.070 & 0.005 & 1.543 & & \\
\hline & 3.011 & 50.834 & 0.005 & 1.200 & $y=\frac{100}{1+10^{\wedge}[(0,4725-x) * 2,138]}$ & \\
\hline & 3.513 & 60.463 & 0.010 & 2.010 & $\mathrm{R}^{2}=0.9969$ & \\
\hline & 4.014 & 64.600 & 0.007 & 1.285 & & \\
\hline & 4.516 & 70.669 & 0.027 & 4.512 & & \\
\hline \multirow{6}{*}{$\begin{array}{c}\text { methanol } \\
\text { extract }\end{array}$} & 4.011 & 34.987 & 0.006 & 2.565 & \multirow{6}{*}{$\begin{array}{c}y=15,6115+4,6372 x \\
R^{2}=0.983\end{array}$} & \multirow{6}{*}{7.416} \\
\hline & 5.014 & 37.339 & 0.004 & 1.752 & & \\
\hline & 6.017 & 44.110 & 0.004 & 1.407 & & \\
\hline & 7.020 & 49.067 & 0.004 & 1.376 & & \\
\hline & 8.022 & 51.434 & 0.008 & 2.390 & & \\
\hline & 9.025 & 58.089 & 0.006 & 1.482 & & \\
\hline
\end{tabular}


Table 3: Inhibition percentage and $\mathrm{IC}_{50}$ values of baicalein

\begin{tabular}{ccccccc}
\hline Sample & $\begin{array}{c}\text { Sample } \\
\text { Concentration } \\
(\boldsymbol{\mu g} / \mathbf{m L})\end{array}$ & $\begin{array}{c}\text { Inhibition } \\
\text { Percentage } \\
(\%)\end{array}$ & $\begin{array}{c}\text { Standard } \\
\text { Deviation } \\
(\text { (SD) }\end{array}$ & $\begin{array}{c}\text { Coefficient } \\
\text { of Variation } \\
(\%)\end{array}$ & Regression equation & $\begin{array}{c}\mathrm{IC}_{50} \\
(\mu \mathbf{g} / \mathbf{m L})\end{array}$ \\
\hline \multirow{5}{*}{ Baicalein } & 0.104 & 23.900 & 0.030 & 1.408 & & \\
& 0.130 & 29.431 & 0.053 & 2.607 & & \\
& 0.156 & 34.371 & 0.022 & 1.073 & $\mathrm{y}=5.7998+176.7657 \mathrm{x}$ & 0.250 \\
& 0.182 & 37.664 & 0.041 & 2.132 & $\mathrm{R}^{2}=0.991$ & \\
\hline
\end{tabular}

Table 4: Inhibition percentage and $I_{50}$ value of the leaves extract of $G$. hombroniana

\begin{tabular}{|c|c|c|c|c|c|c|}
\hline Sample & $\begin{array}{c}\text { Sample } \\
\text { Concentration } \\
(\mu \mathrm{g} / \mathrm{mL})\end{array}$ & $\begin{array}{c}\text { Inhibition } \\
\text { Percentage } \\
\text { (\%) }\end{array}$ & $\begin{array}{l}\text { Standard } \\
\text { Deviation } \\
\text { (SD) }\end{array}$ & $\begin{array}{l}\text { Coefficient } \\
\text { of Variation } \\
\text { (\%) }\end{array}$ & Regression Equation & $\begin{array}{c}\mathrm{IC}_{50} \\
(\mu \mathrm{g} / \mathrm{mL})\end{array}$ \\
\hline \multirow{6}{*}{ n-hexane extract } & 1.249 & 37.679 & 0.029 & 2.290 & \multirow{6}{*}{$\begin{array}{c}y=17.8651+15.6631 x \\
R^{2}=0.972\end{array}$} & \multirow{6}{*}{2.052} \\
\hline & 1.499 & 39.561 & 0.007 & 0.531 & & \\
\hline & 1.998 & 47.222 & 0.003 & 0.261 & & \\
\hline & 2.498 & 61.290 & 0.045 & 4.214 & & \\
\hline & 3.497 & 75.045 & 0.014 & 2.618 & & \\
\hline & 3.997 & 77.240 & 0.025 & 4.624 & & \\
\hline \multirow{6}{*}{ ethyl acetate extract } & 0.075 & 32.019 & 0.022 & 2.636 & \multirow{6}{*}{$\begin{array}{c}y=7.1961+319.3169 x \\
R^{2}=0.980\end{array}$} & \multirow{6}{*}{0.134} \\
\hline & 0.100 & 40.431 & 0.014 & 1.773 & & \\
\hline & 0.126 & 45.426 & 0.019 & 2.654 & & \\
\hline & 0.151 & 52.261 & 0.021 & 3.138 & & \\
\hline & 0.176 & 66.194 & 0.005 & 0.790 & & \\
\hline & 0.201 & 71.241 & 0.019 & 3.072 & & \\
\hline \multirow{6}{*}{ methanol extract } & 0.251 & 35.058 & 0.030 & 2.768 & \multirow{6}{*}{$\begin{array}{c}\mathrm{y}=32.8619+13.0391 \mathrm{x} \\
\mathrm{R}^{2}=0.984\end{array}$} & \multirow{6}{*}{1.314} \\
\hline & 0.501 & 39.962 & 0.051 & 5.004 & & \\
\hline & 1.254 & 49.555 & 0.010 & 0.713 & & \\
\hline & 1.504 & 54.271 & 0.011 & 0.795 & & \\
\hline & 1.755 & 55.241 & 0.043 & 3.289 & & \\
\hline & 2.006 & 57.882 & 0.004 & 0.274 & & \\
\hline
\end{tabular}

Table 5: Calibration curve of quercetin

\begin{tabular}{cccccc}
\hline Sample & $\begin{array}{c}\text { Sample } \\
\text { Concentration } \\
(\boldsymbol{\mu g} / \mathbf{m L})\end{array}$ & $\begin{array}{c}\text { Absorption } \\
(\mathbf{A})\end{array}$ & $\begin{array}{c}\text { Standard } \\
\text { Deviation } \\
(\text { SD) }\end{array}$ & $\begin{array}{c}\text { Coefficient } \\
\text { of Variation } \\
(\%)\end{array}$ & $\begin{array}{c}\text { Linear Regression Equation } \\
\text { Quercetin }\end{array}$ \\
2.012 & 0.235 & 0.006 & 2.009 & \\
& 4.024 & 0.301 & 0.002 & 0.403 & $\mathrm{y}=0.1393+0.0431 \mathrm{x}$ \\
& 6.036 & 0.410 & 0.003 & 0.612 & $\mathrm{R}^{2}=0.995$ \\
& 8.048 & 0.472 & 0.013 & 2.186 & \\
\hline
\end{tabular}




\section{DISCUSSION}

\section{Antioxidant Activity Assay}

Test of antioxidant activity using baicalein as the positive control to ensure that the testing method performed properly and can be used. Baicalein works by binding to the iron element and undergoes oxidation to slow or prevent the oxidation of other molecules. ${ }^{4}$

The capacity percentage of baicalein is better compared to the sample leaves extract of $G$. hombroniana. This may cause by baicalein is a purely positive control (there are no impurities or other compounds), whereas the leaves extract of $G$. hombroniana contains various compounds that attracted during the extraction process and not all of the compounds are reducing agents to FRAP. Ethyl acetate extract of leaves of G. hombroniana has the best antioxidant activity presumably because the ethyl acetate extract contains higher flavonoid than another extract.

\section{Lipoxygenase Enzyme Inhibition Assay}

Lipoxygenase inhibition test is done by using baicalein as a positive control to ensure that the testing method performed properly and can be used. Baicalein acts as an inhibitor which will inhibit the reaction between lipoxygenase and linoleic acid.

Inhibition of lipoxygenase caused by the presence of phenolic compounds such as flavonoid that work as a reductive inhibitor. ${ }^{4}$ Ethyl acetate extract of leaves of G. hombroniana has the best inhibition activity presumably because the ethyl acetate extract contains flavonoid higher than another extract.

\section{Thin Layer Chromatography (TLC) Analysis}

Analysis of TLC using stationary phase silica gel $60 \mathrm{~F}_{254}$ and the mobile phase is different for each extract because the extract obtained by maceration process so that each has different polarity. Mobile phase nhexane and ethyl acetate (6:4) is used for n-hexane extract; mobile phase toluene, ethyl acetate and formic acid (61:30:9) is used for ethyl acetate extract; and mobile phase ethyl acetate and formic acid (40:1) is used for methanol extract.

The TLC result showed that there aren't any flavonoid in the n-hexane and methanol extract, but there is flavonoid in the ethyl acetate extract of the leaves of $G$. hombroniana. The absence of flavonoid in the methanol extract may cause by the abundance of chlorophyll which causes most of the spot produced red color at $366 \mathrm{~nm}^{5}$

\section{Determination of the total flavonoid content (TFC)}

The antioxidant activity and inhibition of lipoxygenase activity contained in the leaves extract of $G$. hombroniana presumably caused by the presence of flavonoid, but the result showed that the ethyl acetate extract of leaves of $G$. hombroniana has the low level of flavonoid. In the previous study, xanton was found at the twigs of G.hombroniana. ${ }^{7}$ The antioxidant activity and inhibition of lipoxygenase activity in leaves extract of $G$. hombroniana may be caused by xanton and other compounds that have antioxidant activity and may inhibit lipoxygenase activity.

\section{CONCLUSION}

Based on the research that has been done, it can be concluded that the ethyl acetate extract of leaves of Garcinia hombroniana Pierre has the most active antioxidant activity and also the most active in inhibiting lipoxygenase activity. Total flavonoid content of ethyl acetate extract of the leaves of Garcinia hombroniana Pierre is $42.004 \mathrm{mg}$ QE/g sample.

\section{ACKNOWLEDGEMENT}

This study was supported by Center of Natural Product, Faculty of Pharmacy, Universitas Indonesia via Hibah PITTA 2016.

\section{CONFLICT OF INTEREST}

None

\section{REFERENCES}

1. Lü J, Lin PH, Yao Q, Chen, C. Chemical and Molecular Mechanisms of Antioxidants: Experimental Approaches and Model Systems. Journal Compilation Foundation for Cellular and Molecular Medicine. 2010;14(4), 840-860. https://doi. org/10.1111/j.1582-4934.2009.00897.x PMid:19754673 PMCid:PMC2927345.

2. Nargis $\mathrm{J}$, et al. Antioxidant, Anti-Cholinesterase and Antibacterial Activities of The Bark Extracts of Garcinia hombroniana. African Journal of Pharmacy and Pharmacology. 2013;7(8):454-9. https://doi.org/10.5897/AJPP12.944.

3. Elya B, Katrin, Mun'im A, Hasiholan A, Marlin I, Mailandari M. Antioxidant Activities of Leaves Extracts of Three Species of Garcinia. International Journal of Medicinal and Aromatic Plants. 2012;2(4):691-3.

4. Deschamps JD, Kenyon VA, Holman TR. Baicalein is A Potent In Vitro Inhibitor Against Both Reticulocyte 15-Human and Platelet 12-Human Lipoxygenases. Bioorganic and Medicinal Chemistry. 2006;14:4295-301. https://doi. org/10.1016/j.bmc.2006.01.057 PMid:16500106.

5. Santosa D, Haresmita PP. Antioxidant Activity Determination Garcinia dulcis (Roxb.) Kurz, Blumeamollis (D.Don) Merr., Siegesbeckia orientalis L., and Salvia riparia H. B. K Which Collected from Taman Nasional Gungung Merapi Using DPPH (2, 2-Diphenyl-1-Pikril-Hidrazil) and Thin Layer Chromatography. Traditional Medicine Journal. 2015;20(1):28-36

6. Bhaigyabati T, Devi PG, Bag GC. Total Flavonoid Content and Antioxidant Activity of Aqueous Rhizome Extract of Three Hedychium Species of Manipur Valley. Research Journal of Pharmaceutical, Biological and Chemical Sciences. 2014;5(5):970-6.

7. Klaiklay S, Sukpondma $Y$, Rukachaisirikul V, Phongpaichit S. Friedolanostanes and Xanthones from The Twigs of Garcinia hombroniana. Phytochemistry. 2013:85:161-6. https://doi.org/10.1016/j.phytochem.2012.08.020 PMid:23022020.

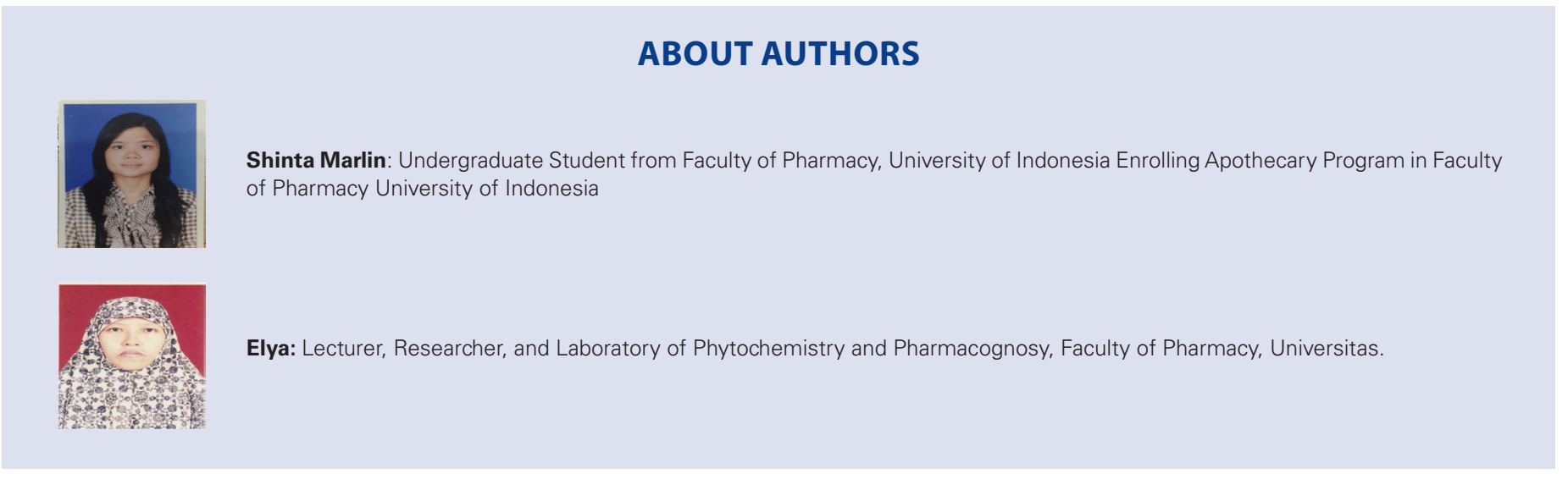


Katrin: Lecturer, Researcher, and Laboratory of Phytochemistry and Pharmacognos, Faculty of Pharmacy, University of Indonesia, INDONESIA.

Cite this Article: Marlin S, Elya B, Katrin. Antioxidant Activity and Lipoxygenase Enzyme Inhibition Assay with Total Flavonoid Content from Garcinia hombroniana Pierre Leaves. Pharmacogn J. 2017; 9(2):267-72. 